\title{
Uji Aktivitas Antidiabetes dari Ekstrak Metanol Buah Kiwi (Actinidia deliciosa) melalui Penghambatan Aktivitas a-Glukosidase
}

\author{
(Antidiabetic Activity of Kiwi Fruit (Actinidia deliciosa) Extract through Inhibition of a- \\ Glucosidase Activity)
}

Okpri Meila*, Noraini

Fakultas Farmasi, Universitas 17 Agustus 1945, Jalan Sunter Permai Jaya, Jakarta Utara 14356

\author{
Article Info: \\ Received: 02Juli 2017 \\ in revised form: 18 Juli 2017 \\ Accepted: 30 Agustus 2017 \\ Available Online: 01Oktober 2017 \\ Keywords: \\ Diabetes melitus, \\ Phytochemicals, \\ Kiwi fruit \\ Actinidia deliciosa \\ $\mathrm{IC}_{50}$.
}

Corresponding Author:

Okpri Meila

Fakultas Farmasi

Universitas 17 Agustus 1945, Indonesia

Phone : +62 82123677577

Email: okprimeila@gmail.com

\begin{abstract}
Diabetes melitus (DM) is defined as a chronic metabolic disease or disorder with multiple etiologies characterized by high blood sugar levels. One way to treat diabetes mellitus is inhibiting the $\alpha$-glucosidase enzyme. This study aims to determine the inhibition of $\alpha$-glucosidase of methanol extract of kiwi fruit (Actinidia deliciosa) . Kiwi fruit (Actinidia deliciosa) contains saponins characterized by the formation of foam, positive flavonoid characterized by the formation of a yellow color (orange) and positive alkaloid which is characterized by brown color in wagner test. The inhibition activity test of $\alpha$ glucosidase enzyme was performed by using spectrophotometric method. The results of the inhibition activity test of $\alpha$-glucosidase enzyme in acarbose showed the value of $13,672 \mu \mathrm{g} / \mathrm{mL}$, while the methanol extract of kiwi fruit showed $\mathrm{IC}_{50}$ value of $7.219 \mu \mathrm{g} / \mathrm{mL}$. It demonstrated that the methanol extract of kiwi fruit has the inhibition activity greater than acarbose.
\end{abstract}




\begin{abstract}
ABSTRAK
Diabetes melitus (DM) didefinisikan sebagai suatu penyakit atau gangguan metabolisme kronis dengan multi etiologi yang ditandai dengan tingginya kadar gula darah. Salah satu cara pengobatan diabetes melitus adalah dengan mekanisme kerja penghambatan enzim $\alpha$-glukosidase. Penelitian ini bertujuan untuk mengetahui penghambatan enzim $\alpha$-glukosidase pada ekstrak metanol buah kiwi (Actinidia deliciosa). Buah kiwi (Actinidia deliciosa) mengandung saponin yang ditandai dengan terbentuknya busa, positif flavonoid yang ditandai dengan terbentuknya warna kuning (jingga) dan positif alkaloid dengan terbentuknya endapan warna coklat pada uji wagner. Pengujian aktifitas penghambatan enzim $\alpha$ glukosidase menggunakan metode spektrofotometri. Hasil uji aktivitas penghambatan enzim $\alpha$-glukosidase pada acarbose menunjukan nilai 13,672 ug/mL sedangkan ekstrak metanol buah kiwi menunjukkan nilai $\mathrm{IC}_{50}$ sebesar 7,219 ug/mL. Hal ini menunjukkan bahwa ekstrak metanol buah kiwi memiliki aktivitas penghambatan enzim $\alpha$-glukosidase lebih besar dari pada akarbose.
\end{abstract}

Kata Kunci : Diabetes Melitus, Fitokimia, Buah kiwi (Actinidia deliciosa), $\mathrm{IC}_{50}$.

\section{PENDAHULUAN}

Diabetes melitus (DM) merupakan salah satu masalah kesehatan yang besar. Data dari studi global menunjukan bahwa jumlah penderita Diabetes Melitus pada tahun 2011 telah mencapai 366 juta orang. Jika tidak ada tindakan yang dilakukan, jumlah ini diperkirakan akan meningkat menjadi 552 juta pada tahun 2030 (IDF, 2011). Diabetes mellitus telah menjadi penyebab dari 4,6 juta kematian.

Diabetes mellitus (DM) didefinisikan sebagai suatu penyakit atau gangguan metabolisme kronis dengan multi etiologi yang ditandai dengan tingginya kadar gula darah disertai dengan gangguan metabolisme karbohidrat, lipid, dan protein sebagai akibat insufisiensi fungsi insulin. Penyebab dari insufisiensi fungsi insulin adalah defisiensi produksi insulin oleh sel-sel $\beta$ Langerhans kelenjar pankreas atau kurang responsifnya sel-sel tubuh terhadap insulin

Salah satu cara pengobatan diabetes melitus tipe 2 yaitu dengan penghambatan kerja enzim $\alpha$ glukosidase yang berperan dalam konversi karbohidrat menjadi glukosa. Dengan dihambatya kerja enzim $\alpha$-glukosidase kadar glukosa dalam darah dapat dikembalikan dalam batas normal (Bösenberg, 2008).

Banyak tumbuhan yang mengandung senyawa bioaktif seperti glukosida, alkaloid, terpenoid, dan flavonoid mempunyai aktifitas sebagai antioksidan dan antidiabetes (Suarsana, et al. 2008). Salah satu tumbuhan tersebut adalah buah kiwi sebagai antioksidan. Berdasarkan penelitian Msc Herry Santoso, Senyawa yang di miliki buah kiwi
(Actinidia deliciosa) adalah flavonoid dan polifenol. Diketahui bahwa buah kiwi mengandung zat-zat yang dapat dimanfaatkan sebagai antioksidan karena kemampuannya melindungi DNA didalam inti sel manusia dari kerusakan akibat radikal bebas, untuk menghambat penuaan dini dan beberapa jenis penyakit degeneratif, untuk mencegah kanker dan kardiovaskuler, penyumbatan darah, stroke dan tekanan darah tinggi, gagal ginjal, diabetes, katarak dan glukoma. Penelitian lain (Anitha Roy, 2011) menyebutkan bahwa buah kiwi mempunyai senyawa bioaktif terutama polipenol. Hal ini menunjukan bahwa buah-buahan dan sayuran mencegah insitol gula alkohol alami pada buah kiwi berperan positif dalam mengatur diabetes. Menurut hasil tersebut, ekstrak metanol buah kiwi memiliki menyerahkan efek yang menguntungkan terhadap penyakit diabetes.

Pengujian aktivitas penghambat enzim $\alpha$ glukosidase dalam penelitian ini dilakukan pada ekstrak metanol dari buah kiwi. pengujian ini menggunakan metode spektrofotometri. Jika ternyata efektif, buah kiwi tersebut sebagai terapi diabetes melitus data penelitian ini akan dijadikan data pendukung pada uji klinis ekstrak buah kiwi terhadap pasien diabetes melitus. Selanjutnya ekstrak ini diharapkan dapat menjadi suplemen dalam terapi pasien diabetes melitus yang pada akhirnya mampu menurunkan morbiditas (angka kesakitan) dan mortalitas (angka kematian) akibat penyakit tersebut. 


\section{METODE PENELITIAN}

\section{Alat}

Timbangan analitik, rotary vacum evaporator (Buchi $\mathrm{R}-125$, Jerman), dan microplate reader.

\section{Bahan}

Bahan kimia yang akan digunakan adalah enzim $\alpha$ glukosidase yang berasal dari rekombinan Saccharomyces cereviasiae (Sigma Aldrich, USA), akarbose, p-nitrofenil- $\alpha$-Dglukopiranosidasi (PNPG) (Wako Pure Chemical Industries Ltd., Jepang), dimetil sulfoksida (DMSO) (Merck, Jerman), Bovine Serum Albumin (BSA) (Merck, Jerman), dan Metanol.

\section{Cara Kerja \\ Pembuatan ekstrak Metanol Buah Kiwi}

Sebanyak 500 gram serbuk buah kiwi diambil dan proses ekstraksi dilakukan dengan menggunakan metode maserasi dengan pelarut metanol. Proses maserasi selama 3 x 24 jam. Kemudian dilakukan penyaringan dan didapat filtratnya. Filtrat yang didapat diuapkan dengan menggunakan rotary evaporator pada suhu $50^{\circ} \mathrm{C}$ hingga diperoleh ekstrak kental yang bebas dari pelarut. Ekstrak Buah Kiwi yang dihasilkan akan digunakan untuk pengujian selanjutnya.

\section{Uji Skrining Fitokimia}

Skrining fitokimia bertujuan untuk mengetahui kandungan metabolit sekunder yang terkandung dalam ekstrak Metanol buah kiwi sehingga dapat diketahui senyawa yang berpotensi sebagai antibakteri.

a. Identifikasi Tanin

Ekstrak kental ditambahkan 3 tetes larutan $\mathrm{FeCl}_{3}$ lalu diamati perubahan warna. Jika terbentuk warna biru kehijauan maka positif tanin (Farnsworth, 1996).

b. Identifikasi Flavonoid

Ekstrak kental $2 \mathrm{~mL}$ ditambahkan $1 \mathrm{~mL} \mathrm{HCl}$ pekat dan ditambahkan 0,05 serbuk $\mathrm{Mg}$. Jika terbentuk busa berwarna merah atau jingga, berarti positif tanin. Kemudian dinginkan dan ditambahkan amil alkohol, kocok. Jika warna merah naik ke atas positif flavonoid. Ekstrak metanol positif terhadap flavonoid dengan terbentuknya warna merah setelah direaksikan dengan $\mathrm{HCl}$ dan serbuk $\mathrm{Mg}$ (Arum et al, 2012).

c. Identifikasi Saponin

Ekstrak kental sebanyak 2-3 mL dimasukkan ke dalam tabung reaksi, lalu dikocok ditambahkan 10 $\mathrm{ml}$ air panas kemudian didinginkan lalu dikocok kuat-kuat selama 10 detik lalu ditambahkan 1 tetes HCL 2 N. Uji positif ditunjukkan dengan terbentuknya buih selama tidak kurang dari 10 menit. Dapat terbentuk busa dikarenakan oleh sifat saponin yang dapat menurunkan tegangan permukaan air. Seperti sabun atau detergen, saponin mempunyai molekul besar yang mengandung gugus hidrofilik dan lipofilik (hidrofobik) (Farnsworth, 1996).

d. Identifikasi Alkaloid

Ekstrak kental buah kiwi ditambahkan dengan $\mathrm{HCl} 2 \mathrm{~N}$. Jika pada penambahan $\mathrm{HCl} 2 \mathrm{~N}$ diperoleh larutan bening, maka dapat langsung diuji dengan pereaksi Meyer, Dragendorf dan Bouchardad. Jika tidak bening, maka tambahkan $\mathrm{NH}_{4} \mathrm{OH}+\mathrm{CHCl}_{3}$, lalu tambahkan $\mathrm{HCl} 2 \mathrm{~N}$, kocok lalu ambil lapisan air dan reaksikan dengan pereaksi Meyer, Dragendrorf dan Bouchardad. Adanya senyawa alkaloid ditunjukkan oleh terjadinya endapan putih dengan pereaksi Meyer, endapan coklat jingga dengan pereaksi Dragendrorf, dan endapan coklat pada pereaksi wagner (Depkes RI, 2000).

e. Identifikasi Triterpenoid

Sebanyak $2 \mathrm{~mL}$ ekstrak buah kiwi ditambahkan $\mathrm{CH}_{3} \mathrm{COOH}$ glasial sebanyak 10 tetes dan $\mathrm{H}_{2} \mathrm{SO}_{4}$ pekat sebanyak 2 tetes. Larutan dikocok perlahan dan dibiarkan selama beberapa menit. triterpenoid memberikan warna merah atau ungu (Harborne, 1987).

\section{Penyiapan Larutan Enzim}

Pembuatan larutan enzim dilakukan dengan cara menimbang 2,9 $\mathrm{mg} \alpha$-glukosidase dan dilarutkan dalam $100 \mathrm{ml}$ larutan dapar fosfat $\mathrm{pH}$ 7,0 yang mengandung $200 \mathrm{mg}$ Bovine Serum Albumin (BSA) dalam kondisi dingin sehingga diperoleh larutan induk $0,8 \mathrm{U} / \mathrm{ml}$. Selanjutnya di pipet $5 \mathrm{ml}$ dari larutan induk enzim, diencerkan dengan dapar fosfat $\mathrm{pH} 7,0$ yang megandung Bovine Serum Albumin (BSA) 200 mg hingga $10 \mathrm{ml}$,kemudian dipipet kembali $1 \mathrm{ml}$ dari pengenceran kemudian di encerkan dengan buffer fosfat $\mathrm{pH} \mathrm{7,0} \mathrm{hingga} 10 \mathrm{ml}$. hingga diperoleh larutan enzim $0,01 \mathrm{U} / \mathrm{mL}$. Larutan enzim dapat disimpan dalam freezer dengan temperature $-20^{\circ} \mathrm{C}$ dan tetap stabil hingga 1 bulan.

\section{Penyiapan Larutan StandarAkarbose}

Ditimbang $100 \mathrm{mg}$ akarbose kemudian dilarutkan dalam buffer fosfat $10 \mathrm{ml}$. hingga di dapatkan konsentrasi $10 \mathrm{ug} / \mathrm{mL}$. kemudian dilakukan pengenceran sampai diperoleh konsentrasi larutan 
0,25 ug/mL, $1 \mathrm{ug} / \mathrm{mL}, 2 \mathrm{ug} / \mathrm{mL}, 5 \mathrm{ug} / \mathrm{mL}, 7 \mathrm{ug} / \mathrm{mL}$ dan $10 \mathrm{ug} / \mathrm{mL}$.

\section{Persiapan Ekstrak}

Ekstrak sebanyak $10 \mathrm{mg}$ dilarutkan dengan 100 $\mu \mathrm{L}$ dimetil sulfoksida (DMSO) kemudian dicukupkan volumenya dengan dapar fosfat $\mathrm{pH}$ 7,0 pada labu ukur $10 \mathrm{ml}$ sehingga diperoleh larutan ekstrak dengan konsentrasi $10.000 \mathrm{ug} / \mathrm{mL}$, selanjutnya dilakukan pengenceran menjadi $125 \mathrm{ug} / \mathrm{mL}, 250 \mathrm{ug} / \mathrm{mL}, 500$ $\mathrm{ug} / \mathrm{mL}, 1000 \mathrm{ug} / \mathrm{mL}, 1500 \mathrm{ug} / \mathrm{mL}$ dan $2000 \mathrm{ug} / \mathrm{mL}$.

\section{Uji Efek Inhibisi $\alpha$-Glukosidase}

Pada ekstrak metanol, dilakukan uji efek inhibisi $\alpha$-glukosidase.

a. Pengujian Blanko

Larutan dapar fosfat $\mathrm{pH}$ 7,0 sebanyak $50 \mu \mathrm{L}$ ditambahkan dengan $10 \mu \mathrm{L}$ larutan dimetil sulfoksida (DMSO), $25 \mu \mathrm{L}$ paranitrofenil $\alpha$-D- glukopiranosida dengan konsentrasi $10 \mathrm{mM}$, dan enzim $\alpha$ glukosidase $0,01 \mathrm{U} / \mathrm{mL}$ sebanyak $25 \mu \mathrm{L}$. Kemudian campuran diinkubasi selama 30 menit pada suhu $37^{\circ} \mathrm{C}$. Setelah masa inkubasi selesai, ditambahkan $100 \mathrm{~mL} \mathrm{~N} \mathrm{a}_{2} \mathrm{CO}_{3} 200 \mathrm{mM}$. Larutan kemudian diukur adsorbansinya dengan microplate reader pada panjang gelombang $410 \mathrm{~nm}$.

b. Pengujian Sampel

Larutan dapar fosfat $\mathrm{pH} 7,0$ sebanyak $50 \mu \mathrm{L}$ ditambahkan dengan $10 \mathrm{~mL}$ larutan sampel (ekstrak) yang konsentrasinya $125 \mathrm{ug} / \mathrm{mL}, 250 \mathrm{ug} / \mathrm{mL}, 500 \mathrm{pm}$, $1000 \mathrm{ug} / \mathrm{mL}, 1500 \mathrm{ug} / \mathrm{mL}, 2000 \mathrm{ug} / \mathrm{mL}$ dan juga ditambahkan $25 \mu \mathrm{L}$ p-nitrofenil- $\alpha$-D-glukopiranosida dengan konsentrasi $10 \mathrm{mM}$ Campuran diinkubasi selama selama 30 menit pada suhu $37^{\circ} \mathrm{C}$ lalu ditambahkan $25 \mu \mathrm{L}$ laruitan enzim dengan konsentrasi $0,01 \mathrm{U} / \mathrm{mL}$. Setelah masa inkubasi selesai, kemudian ditambahkan $100 \mu \mathrm{L} \mathrm{Na}_{2} \mathrm{CO}_{3} 200$ mM. Larutan sampel kemudian diukur absorbansinya dengan microplate reader pada panjang gelombang $410 \mathrm{~nm}$.

c. Pengujian Larutan Standar Akarbose

Larutan dapar fosfat $\mathrm{pH} 7,0$ sebanyak $50 \mu \mathrm{L}$ ditambahkan dengan $10 \mu \mathrm{L}$ larutan sampel yang konsentrasinya $0,25 \mathrm{ug} / \mathrm{mL}, 1 \mathrm{ug} / \mathrm{mL}, 2 \mathrm{ug} / \mathrm{mL}, 5$ $\mathrm{ug} / \mathrm{mL}, 7 \mathrm{ug} / \mathrm{mL}, 10 \mathrm{ug} / \mathrm{mL}$ dan $25 \mu \mathrm{L}$ p-nitrofenil- $\alpha$ D-glukopiranosida dengan konsentrasi $10 \mathrm{mM}$, enzim $\alpha$-glukosidase $25 \mu \mathrm{L}$, kemudian diinkubasi selama 30 menit pada suhu $37^{\circ} \mathrm{C}$. Setelah masa inkubasi selesai, tambahkan $100 \mu \mathrm{L} \mathrm{Na} \mathrm{CO}_{3} 200 \mathrm{~nm}$. Larutan sampel diukur adsorbansinya dengan microplate reader pada panjang gelombang $410 \mathrm{~nm}$.
Persen penghambatan dihitung menggunakan rumus:

$$
\begin{gathered}
\% \text { hambatan }=\frac{c-s}{c} \\
\text { Keterangan }: \mathrm{S}=\text { absorbansi sampel } \\
\mathrm{C}=\text { absorbansi kontrol (Blanko DMSO) }
\end{gathered}
$$

Sedangkan, $\mathrm{IC}_{50}$ dihitung dengan menggunakan persamaan regresi linear, konsentrasi sampel sebagai sumbu $\mathrm{x}$ dan $\%$ inhibisi sebagai sumbu $\mathrm{y}$.

Dari persamaan: $\mathrm{y}=\mathrm{a}+\mathrm{bx}$ dapat dihitung nilai $\mathrm{IC}_{50}$ dengan menggunakan rumus:

$$
\mathrm{IC}_{50}=\frac{50-a}{b}
$$

\section{HASIL DAN PEMBAHASAN \\ Pemeriksaan organoleptis ekstrak}

Adapun organoleptis yang dihasilkan adalah : Ekstrak yang diperoleh berbentuk cairan kental, berwarna coklat dan berbau khas

Hasil ekstraksi buah kiwi dengan pelarut metanol menghasilkan bobot ekstrak sebesar 119 gram dengan nilai rendemen $23,81 \%$. Untuk nilai susut pengering yang diperoleh dari ekstrak metanol buah kiwi sebesar 6,86\%.

Maserasi dilakukan selama 3 x 24 jam. Filtrat hasil ekstraksi tersebut disaring agar terpisah dari residunya. Seluruh filtrat yang didapat ditampung dan diuapkan dengan menggunakan rotary evaporator pada suhu $50^{\circ} \mathrm{C}$ hingga metanol menguap seluruhnya Keuntungan penggunaan rotary evaporator yaitu suhu pada proses penguapan dapat dikontrol sehingga dapat menghindari kerusakan zat aktif karena pemanasan. Selanjutnya ekstrak metanol yang diperoleh, ditimbang untuk menghitung rendemen. (Depkes RI, 2000).

Ekstrasi cara maserasi dipilih karena metode maserasi adalah salah satu metode ektraksi cara dingin yang mudah dilakukan karena alat dan caranya sederhana, dan memungkinkan senyawa aktif yang terkandung didalam simplisia tidak rusak karena cara dingin dapat digunakan untuk simplisia yang tahan dan tidak tahan akan pemanasan. Sedangkan metode ekstraksi cara panas hanya dapat digunakan untuk simplisia yang tahan dalam pemanasan. Bila dibandingkan dengan metode cara dingin yang lain (perkolasi), metode maserasi di nilai lebih efisien dan mudah dilakukan, karena metode perkolasi membutuhkan waktu ektraksi dan pelarut yang lebih banyak

$\begin{array}{rrlr}\text { Skrining } & \text { Fitokimia dilakukan terhadap } \\ \text { senyawa kimia } & \text { golongan } & \text { alkaloid, flavonoid, }\end{array}$


saponin, tanin dan triterpenoid dari ekstrak metanol buah kiwi. Dari hasil skrining fitokimia dapat disimpulkan bahwa ekstrak metanol dari buah kiwi (Actinidia deliciosa) positif mengandung flavonoid, saponin dan alkaloid pada uji wagner.

Metanol dapat menarik alkaloid, steroid, saponin, dan flavonoid dari tanaman (Thompson,1985). Penelitian Suryanto (2009) menunjukkan bahwa metanol mampu menarik lebih banyak jumlah metabolit sekunder yaitu senyawa fenolik, flavonoid, dan tanin.

Sebelum dilakukan uji aktivitas penghambat enzim $\alpha$-glukosidase, uji pendahuluan dilakukan terlebih dahulu, yang bertujuan untuk mencari kondisi yang optimum untuk uji aktivitas enzim. Prinsip uji pendahuluan dan aktivitas penghambatan enzim $\alpha$-glukosidase adalah enzim $\alpha$ - glukosidase akan menghidrolisis p-nitrofenil- $\alpha$-D-glukopiranosida menjadi p-nitrofenol yang berwarna kuning dan glukosa. Aktivitas enzim diukur berdasarkan hasil absorbansi warna kuning p-nitrofenol (Sugiwati dkk, 2009). Uji aktivitas penghambat enzim $\alpha$-glukosidase digunakan metode spektrofotometri. . Faktor koreksi dibuat untuk sampel (S) dan blanko (B). Koreksi sampel meliputi dua hal yaitu memastikan bahwa natrium karbonat benar-benar sudah menghambat kerja enzim dan mengetahui apakah ada absorbansi yang terbaca dari senyawa selain p-nitrofenol dengan spektrofotometer UV-Vis pada panjang gelombang 410 nm. (Dewi, et al. 2007).

Pengujian di lakukan dengan berbagai konsentrasi ekstrak buah kiwi agar mengetahui pengaruh konsentrasi ekstrak terhadap daya inhibisi yang dapat dinyatakan dalam persen inhibisi atau $\mathrm{IC}_{50}$. Persen inhibisi menunjukkan jumlah persentase enzim yang dihambat oleh konsentrasi sampel, sehingga makin besar nilai persen menunjukkan makin besar inhibisinya terhadap enzim, dan sebaliknya (Hardoko dkk, 2015). IC I0 $_{50}$ menunjukkan kemampuan dari sampel dalam menghambat aktivitas enzim sebesar 50 persen, sehingga makin kecil nilai $\mathrm{IC}_{50}$ menunjukkan aktivitas inhibisi makin tinggi, dan sebaliknya. Mardawati et al (2008) menyatakan bahwa $\mathrm{IC}_{50}<50 \mathrm{ug} / \mathrm{mL}$ sangat kuat jika bernilai 50$100 \mathrm{ug} / \mathrm{mL}$, sedang jika $\mathrm{IC}_{50}$ bernilai $100-150 \mathrm{ug} / \mathrm{mL}$, lemah jika $\mathrm{IC}_{50}$ adalah $150-200 \mathrm{ug} / \mathrm{mL}$, dan sangat lemah jika nilai $\mathrm{IC}_{50}>200 \mathrm{ug} / \mathrm{mL}$. Pengujian terhadap akarbose digunakan sebagai acuan atau pembanding pada pengujian terhadap ekstrak metanol . Akarbose mempunyai $\mathrm{IC}_{50}$ sebesar $13,672 \mathrm{ug} / \mathrm{mL}$, sedangkan ekstrak metanol buah kiwi, persamaan regresi linier yang diperoleh adalah $\mathrm{y}=-12,618+8,673 \mathrm{x}$. Dari persamaan regresi linier tersebut diperoleh nilai koefisien korelasi ( $\mathrm{r}$ atau $\mathrm{r}^{2}$ ) sebesar 0,971 dan $\mathrm{IC}_{50}$ pada ekstrak metanol buah kiwi sebesar 7,219 $\mathrm{ug} / \mathrm{mL}$. Berdasarkan hasil uji aktivitas ekstrak metanol buah kiwi, apabila dilihat hasil $\mathrm{IC}_{50}$ yang dicapai maka ekstrak metanol buah kiwi memiliki nilai hambatan yang lebih besar dari akarbose

\section{KESIMPULAN}

Berdasarkan penelitian yang telah dilakukan, maka dapat ditarik kesimpulan sebagai berikut: Hasil uji aktivitas penghambatan enzim $\alpha$-glukosidase pada akarbose menunjukan nilai $\mathrm{IC}_{50} \quad 13,672 \mathrm{ug} / \mathrm{mL}$ termasuk katagori kuat, sedangkan ekstrak Metanol buah kiwi menunjukkan nilai $\mathrm{IC}_{50}$ sebesar 7,219 $\mathrm{ug} / \mathrm{mL}$ hal ini menunjukkan bahwa ekstrak metanol buah kiwi memiliki aktivitas penghambatan $\alpha$ glukosidase, hal ini menunjukkan aktivitas ekstrak etanol buah kiwi menghambat $\alpha$-glukosidase lebih kuat daripada akarbose.

\section{DAFTAR PUSTAKA}

Arum YP, Supartono, Sudarmin. (2012). Isolasi dan Uji Daya Antimkroba Ekstrak Daun Kersen (Muntingia calabura), Jurnal MIPA, 35(2), 165-174

Bosenberg, L. H. (2008). The mechanism of action of oral antidiabetic drugs :a review of recent literatur. The Journal of Endocrinolgy, Metabolism andDiabetes of South Africa, 13(3),80-88

Departemen Kesehatan Republik Indonesia, (2000). Parameter Standar Umum Ekstrak Tumbuhan Obat, Jakarta

Farnsworth, N.R, (1996), Biological and Pytochemical Screening of Plants, Journal of Pharmaceutical Sciences, 55(3), 226-227

Hardoko, Febriani A, Siratantri T. (2015). Aktivitas Antidiabet Secara In vitro Agar-agar, Agarosa, Dan Agaropektin Dari Rumput Laut Gracilaria gigas. Jurnal pengolahan Hasil Perikanan Indonesia, 18(2), 128-139

Harborne JB. (1987). Metode Fitokimia, Bandung, ITB

International Diabetes Federation. (2011). Diabetes Evidence Demands Real Action From The 
Un Summit On Non-Communicable Diseases, retrieved from http://www.idf.org/diabetesevidence-demands-real-action-un- summitnon-communicable-diseases.

International Diabetes Federation. (2011). One Adult In Ten Will Have Diabetes By 2030. Retrueved fromhttp://www.idf.org/mediaevents/press-releases/2011/diabetes-atlas8th-edition.

Mardawati E, Filianty F, Marta H. (2008). Kajian Aktivitas Antioksidan Ekstrak Kulit Manggis (Garcinia Mangostana L ) Dalam Rangka Pemanfaatan Limbah Kulit Manggis Di Kecamatan Puspahiang Kabupaten Tasikmalaya, Jurnal Teknotan, 2(3)

Sugiwati, Sri., Siswati Setiasih, \& Efy Afifah. (2009). Antihyperglycemic activity of the mahkota dewa (Phalerria macrocarpa (Scheff.) Boerl.J leaf extracts as an alphaglucosidase inhibitors. Makara Kesehatan, 3(2), hal berapa? .

Suryanto E, \& Katja DG. (2009). Aktivitas Penangkal Radikal bebas dan Penstabil Oksigen Singlet dari Ekstrak Daun Kunyit (Curcuma domestica Val.), Chemistry Progress., 2(2); 87-95

Thompson, E. B. (1985). Drug Bioscreening. America, Graceway Publishing Company, Inc. Pp. 40, 118.

Roy, Anitha \& friends. (2011). Edible FruitsNature's Gift For Diabetes paritients -A Comprhensive Review. Retrieved from http: // globalresearchonline.net/jounalcontents/ volume9issue2/article-029.pdf. 